\title{
losepho Nowacki post obitum anno quadragesimo
}

\author{
Napisat I poświęca pamięcl SWego nauczyciela Historiı KoŚciota \\ W CZTERDZIFSTOLFCIE JEGO ODEŚCIA, W IMIENIU SWOIM I TYCH, KIÓRTY CHCIELBBY MU PODZIIÉKOWAĆ
}

\section{FELIKS LENORT}

W historiografii kościelnej Wielkopolski ksiądz Józef Nowacki posiada miejsce utrwalone i zgoła wyjątkowe nie tylko dlatego, iż jako nieprzeciętny analityk źródeł głównie średniowiecznych, rozwikłał wiele tajemnic naszej przeszłości, ale przede wszystkim z tej racji, iż stworzył monumentalną syntezę dziejów najstarszej diecezji polskiej. Jego obszerne dwutomowe "Dzieje archidiecezji poznańskiej" na długo stanowić będą punkt odniesienia dla wszelkich badań szczegółowych, a w rozumieniu opracowania syntetycznego pozostaną dziełem nie do przecenienia.

Od odejścia księdza Józefa Nowackiego minęło już lat czterdzieści*. Niniejszy drugi tom wydawnictwa "Ecclesia. Studia z Dziejów Wielkopolski” poświęcamy jego pamięci. Korzystamy z okazji, by przywołać podstawowe koleje jego życia i naukowej aktywności.

Ksiądz Józef Nowacki miał kilku pracowitych poprzedników, którzy w badaniach nad dziejami kościelnymi Wielkopolski odegrali rolę ważną i w swoim czasie - zgodnie z ówczesnym stanem wiedzy historycznej i z obowiązującymi wtedy wymogami warsztatu naukowego - stworzyli kompendia dziejów obu wielkopolskich diecezji, wciąż pamiętane i wykorzystywane. Myślę, że trzeba tu wymienić przede wszystkim Józefa Łukaszewicza i księdza Jana Korytkowskiego, ale także księdza Stanisława Kozierowskiego, autora wielotomo-

\footnotetext{
* Niniejszy tekst powstał w roku 2004, a więc dokładnie w czterdziestą rocznicę śmierci księdza Józefa Nowackiego. Z różnych przyczyn ukazuje się dwa lata później.
} 
wego dzieła z zakresu toponomastyki wielkopolskiej, w tym kilku tomów zatytułowanych: „Badania nazw topograficznych dzisiejszej archidiecezji gnieźnieńskiej” (Poznań 1909-1912) i „Badania nazw topograficznych dzisiejszej archidiecezji poznańskiej” (Poznań 1914-1915) oraz dwóch innych pt.: „Szematyzm historyczny ustrojów parafialnych dzisiejszej archidiecezji gnieźnieńskiej” (Poznań 1934) i "Szematyzm historyczny ustrojów parafialnych dzisiejszej archidiecezji poznańskiej" (Poznań 1933).

Na szczególne wszakże podkreślenie w rzędzie poprzedników księdza Józefa Nowackiego zasługuje Józef Łukaszewicz, wielce zasłużony badacz różnowierstwa polskiego, szkolnictwa i wychowania, także dziejów Poznania, ale dla nas tu ważny wspomnienia przede wszystkim jako autor obszernego dzieła pt.: "Krótki opis historyczny kościołów parochialnych, kościółków, kaplic, klasztorów, szkółek parochialnych, szpitali i innych zakładów dobroczynnych w dawnej diecezji poznańskiej", które zostało wydane w trzech tomach w Poznaniu, nakładem Jana Konstantego Żupańskiego, w latach 1858-1863. Od razu jednak trzeba powiedzieć, iż na próżno by tu szukać opisów tajników wewnętrznych dziejów kościelnych. Kościoły nasze są kolebką oświaty i składem pamiątek narodowych - napisał autor w pierwszym zdaniu przedmowy do tego dzieła. Miał świadomość, że rzucają one światło na przeszłość narodu, jego oświatę, obyczaje, sztuki piękne, życie gospodarcze. I takim wzrokiem się posługując dokonał opisu poszczególnych kościołów, klasztorów, szkół, szpitali. Ten drobiazgowy opis poprzedził obszernym, przeszło stustronicowym wstępem, w którym podjął temat początków diecezji, granic, podziałów terytorialnych. Korzystał z obszernych wizytacji biskupów $\mathbf{i}$ archidiakonów od roku 1603, z akt kapitulnych i konsystorskich, z archiwów poszczególnych kościołów. Wykorzystał niepełne niestety opisy kościołów sporządzone co dopiero przez duchowieństwo na polecenie arcybiskupa Teofila Wolickiego z roku 1828. Podzielił całość na archidiakonaty, dekanaty i parafie, opisał wszystko co zauważył, wszystkie ślady materialne, napisy nagrobne. Szczerze wyznał, iż o wielu kościołach, jeśli talent ludzki nie wycisnął na nich swego znamienia, nie ma co mówić. Pytal: Cóż np. powiedzieć o skromnym kościótku wiejskim, z drzewa lub gliny postawionym, strzechą lub gontami pokrytym bez żadnych wewnątrz ozdób i pomników? Cała jego biografia, podobnie jak większej części ludzi, zawiera się w kilku wydatniejszych momentach istnienia, to jest: był postawionym, poświęconym, odprawiało się w nim nabożeństwa, spalit się lub runąt z starości.

\footnotetext{
1 O księdzu Stanisławie Kozierowskim zob. np. opracowanie S. U r b a ń c z y k a W "Polskim słowniku biograficznym" (t. 14, s. 628-629) oraz ostatnio J. L eś n y w pracy zbiorowej pod red. J. Strzelczyka pt.: Wybitni historycy wielkopolscy (Poznań 1989, s. 199208).
} 
To dzieło Łukaszewicza ma - co oczywiste - swoje ograniczenia, do których zresztą sam autor się przyznaje. To wszakże, co zamierzał, wykonał aż nadto dobrze. Nie było to jeszcze pisarstwo historyczne, którym znacznie później obdarzył nas ksiądz Józef Nowacki. Jest wszakże pamiętane i wykorzystywane, o czym świadczy fakt, iż "Krótki opis historyczny kościołów parochialnych [... ] w dawnej diecezji poznańskiej" został wznowiony w roku 1980 w pięknym wydaniu fotooffsetowym przez Archiwum Archidiecezjalne w Poznaniu, z inicjatywy piszącego te słowa, ale głównie dzięki staraniom księdza Konrada Lutyńskiego, przedwcześnie zmarłego w roku 2002. To, że także kolejne dzieło tego autora zostało ostatnio przypomniane, świadczy niewątpliwie o tym, że istnieje mimo upływu czasu - świadomość nieprzemijającej wartości tego pisarstwa. Mowa tu o wznowionym w roku 1998 w Wydawnictwie Miejskim w Poznaniu dwutomowym "Obrazie historyczno-statystycznym miasta Poznania w dawniejszych czasach" (wydanie przygotował Jacek Wiesiołowski)².

Chciałoby się powiedzieć przesadnie, że tym, kim w wielkopolskiej historiografii kościelnej $w$ odniesieniu do diecezji poznańskiej był Józef Łukaszewicz, tym w odniesieniu do archidiecezji gnieźnieńskiej był w pewnym stopniu ksiądz Jan Korytkowski. Byłoby to jednak wyraźnie uproszczenie i tylko w części prawdziwe. Ten drugi bowiem odegrał rolę nieporównanie większą, a przede wszystkim reprezentował znakomicie wyższą świadomość naukowego warsztatu historycznego ${ }^{3}$. Różnica polegała także na tym, iż Łukaszewicz w przytoczonym dziele zajmował się historią kościołów i parafii, Korytkowski - kapitułą i arcybiskupami, prymasami Polski, chociaż - przyznać trzeba, że i historii lokalnej poświęcił nieco uwagi, gdy w roku 1888 w miejsce dorocznego elenchu obu archidiecezji, wydał "Brevis descriptio historico-geographica ecclesiarum Archidioecesis Gnesnensis et Posnaniensis". Dzieło Korytkowskiego jest jedyne w swoim rodzaju. Z ogromną akrybią wykorzystał przebogate gnieźnieńskie zbiory archiwalne, które najpierw kompetentnie uporządkował. Sam wyznał, że stało się to możliwe od czasu, gdy zostawszy kanonikiem

2 Tekst o Józefie Łukaszewiczu w „Polskim słowniku biograficznym” (t. 18, 1973, s. 542 544) jest nie podpisany, sygnowawany jedynie skrótem „Red.", co jest bardzo rzadko stosowaną praktyką w tym zasłużonym wydawnictwie. W dosyć szczegółowym haśle - nie wiadomo dlaczego - „Opis historyczny kościołów parochialnych ... w dawnej diecezji poznańskiej" został pominięty. Zob. także: A. W o j t k o w s k i, Józef Łukaszewicz jako historyk, „Kronika Miasta Poznania”, 14 (1936), nr 1, s. 1-36. Ostatnio życie i dzieło Łukaszewicza przypomniał M. Ko s m a n w pracy zbiorowej pod red. J. Strzelczyka Wybitni historycy wielkopolscy, s. 61-73.

${ }^{3}$ O księdzu Janie Korytkowskim zob. np. M. W o j c i e c h o w s k a w "Polskim słowniku biograficznym" (t. 14, s. 147-149) oraz J. J a s k u I s k i w pracy zbiorowej pod red. J. Strzelczyka Wybitni historycy wielkopolscy, s. 105-113. Zob. także: J. J a skulsk i Dzieło ks. Jana lgnacego Korytkowskiego w ocenie historiografii i metodologii XIX i XX wieku, [w:] Sto lat Archidiecezji Gnieźnieńskiej, pod red. J. Strzelczyka i J. Górnego, Gniezno 2000, s. 407-417. 
gnieźnieńskim zyskał nieograniczony dostęp do ośmiowiekowych skarbów archiwum gnieźnieńskiego. $Z$ zapałem - pisze - zabrałem się do zbadania tej skarbnicy dziejowej $i$ w miarę bliższego poznawania nieocenionych jej zasobów, dojrzewała we mnie coraz większa chęć i pragnienie zużytkowania ich w żywotach nie tylko prymasów naszych, ale całego szeregu prałatów i kanoników metropolitalnych od początku istnienia kapituły aż do dni naszych.

I tak powstały dwa ogromne dzieła o nieprzemijającej wartości: „Prałaci i kanonicy katedry metropolitalnej gnieźnieńskiej od r. 1000 aż do dni naszych" (t. 1-4, Gniezno 1881-1882), w którym pomieścił w układzie alfabetycznym życiorysy ponad 2800 prałatów i kanoników gnieźnieńskich, poprzedzając całość tekstem o dziejach kapituły, oraz drugie: „Arcybiskupi gnieźnieńscy, prymasowie i metropolici polscy od r. 1000 do 1821, czyli do połączenia arcybiskupstwa gnieźnieńskiego z biskupstwem poznańskim" (t. 1-5, Poznań 1887 1892). Po stu przeszło latach trzeba stwierdzić zdecydowanie, iż mimo że w warstwie interpretacyjnej niektóre wątki tych dzieł są poddawane rewizji, to nieprzemijającą jednak wartość zachowała materiałowa warstwa dzieła, któremu niektórzy przesadnie próbują przydać miano ekscerptów z ksiąg archiwalnych gnieźnieńskich. Nawet gdyby taką opinię przyjąć, to i tak dokonania Korytkowskiego posiadają wartość jeszcze bardziej cenną i pożyteczną. Zdaje się, że miał rację ksiądz Władysław Chotkowski, także zasłużony historyk (i podobnie jak Korytkowski urodzony w Trzemesznie), wyrażając opinię, że dzieło to nigdy się nie przestarzeje, ma $w$ literaturze naszej tem większe znaczenie, że w dziejach historiografii kościelnej on pierwszy zdobył się na taką pracę, innym duchownym zaświecił godnym naśladowania przykładem.

Nie będzie przesadą stwierdzenie, że ksiądz Józef Nowacki byl pod nieodpartym wrażeniem tych dziewięciu ogromnych woluminów dzieła Jana Korytkowskiego. Dla niego, ambitnego historyka, brak podobnego opracowania dla poznańskiej części Wielkopolski, musiał być szczególnie boleśnie odczuwany. Postanowił tę lukę wypełnić i w przeważającej mierze udało mu się to urzeczywistnić.

Pochodził z Pomorza, ale prawie całe życie (z wyjątkiem lat szkolnych) związał z Wielkopolską, z Poznaniem4. Urodził się 19 września 1893 roku we

${ }^{4} \mathrm{O}$ księdzu Józefie Nowackim ukazały się cztery wspomnienia pośmiertne: S. H a i n, Śp. Ks. Jozef Nowacki, "Przewodnik Katolicki”, 54 (1964), nr 25, s. 226; K. K a r † o w s k i, Sp. Ks. Józef Nowacki, "Miesięcznik Kościelny Archidiecezji Poznańskiej”, 16 (1965), nr 5, s. 116-117; M. B a n a s z a k, Ksiądz Józef Nowacki - historyk Kościoła w Polsce. (Pośmiertne wspomnienia o działalności naukowej i pedagogicznej), [w:] J. Nowacki, Dzieje Archidiecezji Poznańskiej, t. 2: Archidiecezja Poznańska w granicach historycznych i jej ustrój, Poznań 1964, s. 967-974; M. B a n a s z a k, Śp. ks. prof. Józef Nowacki, "Tygodnik 


wsi Mrocza, w powiecie wyrzyskim. Był synem Jana, mistrza siodlarskiego i Anny z Witeckich. Po ukończeniu szkoły ludowej w Koronowie uczył się w latach 1905-1910 w progimnazjum biskupim (Collegium Marianum) w Pelplinie, które cieszyło się wysoką opinią w zakresie kształcenia, ale także z racji pielęgnowania ducha polskiego. Naukę kontynuował w państwowym gimnazjum w Chełmnie, gdzie 13 lutego 1913 roku uzyskał świadectwo dojrzałości i niezwłocznie zgłosił się do seminarium duchownego w Poznaniu. Zachowało się świadectwo moralności (litterae testimoniales pro saecularibus) z dnia 4 sierpnia 1914 roku, wydane przez biskupa chełmińskiego Augustyna Rosentretera za okres lat szkolnych, które spędzał na terenie tej diecezji. Pozytywną opinię wydał też ksiądz Gustaw Pobłocki, proboszcz we Wtelnie, na terenie której znajdowała się Łęcznica. Właśnie tutaj, u rodziny Palędzkich, właścicieli tamtejszego majątku, spędzał przeważnie miesiące wakacyjne i nie jest pozbawione słuszności domniemanie, że Palędzcy wydatnie opiekowali się nim materialnie. Rozpoczą studia filozoficzno-teologiczne w Poznaniu, bo tu kształcili się klerycy z obu diecezji Wielkopolski, ale po trzech latach - zgodnie z obowiązującą procedurą - przenosili się do Gniezna na roczne tzw. seminarium praktyczne.

Dnia 18 lutego 1917 roku przyjął święcenia kapłańskie w Gnieźnie z rąk arcybiskupa Edmunda Dalbora i niezwłocznie został skierowany na studia specjalistyczne z historii Kościoła na uniwersytet w Münster, gdzie jednak przebywał tylko przez trzy semestry. Musiał je przerwać z powodów zdrowotnych. Powrót do Münster i kontynuacja studiów okazała się niemożliwa z racji nowej sytuacji politycznej w związku z wojną światową.

W roku 1918 miał okazję zastępczo spełniać obowiązki duszpasterskie przy kościele pod wezwaniem świętej Katarzyny w Brzyskorzystewie, w dekanacie kcyńskim. To był - zdaje się - jedyny taki fragment w pełni duszpasterskiego zaangażowania w jego biografii, nie licząc późniejszych, przejściowo przecież wykonywanych obowiązków prefekta, najpierw (od 6 czerwca 1919) w gimnazjum żeńskim Zofii Rzepeckiej w Poznaniu, gdzie był nauczycielem religii i wychowawcą (założył w tej szkole w roku 1921 sodalicję mariańską). Od 1 września 1926 roku te same obowiązki przejął w gimnazjum męskim świętego Jana Kantego w Poznaniu, gdzie też był moderatorem uczniowskiej sodalicji. Wcześniej jednak podjął przerwane z powodów losowych, studia.

Powszechny", 18 (1964), nr 21, s. 15. Ukazało się też pięć biogramów w encyklopediach i słownikach: M. B a n a s z a k W "Polskim słowniku biograficznym" (t. 23, 1978, s. 245246); A. G ą s i o r o w s k i w "Wielkopolskim słowniku biograficznym”, 1981, s. 519; M. B a n a s z a k w "Słowniku polskich teologów katolickich 1918-1981" (t. 6, 1983, s. $552-$ 556); M. B a n a s z a k w "Słowniku pracowników książki polskiej. Suplement" (1986, s. 152-153). Zob. także M. B a n a s z a k, Józef Nowacki 1895-1964, [w:] Wybitni historycy wielkopolscy, s. 287-293. 
Kontynuowal je na nowopowstałym w Poznaniu uniwersytecie, gdzie już 30 lipca 1919 roku otrzymał dyplom nauczyciela szkół średnich w zakresie trzech przedmiotów: religii oraz języków łacińskiego i hebrajskiego.

Lata dydaktyki gimnazjalnej wykorzystał bardzo pracowicie - jak się później okazało - także w służbie swej największej życiowej pasji: nauki historycznej. Przygotował w tym czasie rozprawę doktorską zatytułowaną: Szpital św. Gotarda pod Włocławkiem (klasztor cystersów w latach 1228-1358). Na jej podstawie, dnia 15 maja 1926 roku, na Wydziale Teologicznym Uniwersytetu Jana Kazimierza we Lwowie otrzymał dyplom doktora teologii. Było oczywiste, że czas prefektury szkolnej musiał dobiec końca. Zbliżał się nieuchronnie nowy rozdział w jego życiu, w którym w pełniejszy sposób będzie mógł wykorzystać swoje naukowe kompetencje.

W Poznaniu, w miejscowym Seminarium Duchownym, profesorem historii Kościoła był od roku 1926 ksiądz Henryk Likowski (habilitowany rok wcześniej na uniwersytecie (wowskim), od roku następnego powołany na profesora historii Kościoła na Wydziale Teologicznym Uniwersytetu Warszawskiego. Ksiądz Józef Nowacki był znakomicie przygotowany, by objąć to wakujące stanowisko. Kardynał August Hlond w piśmie z dnia 9 lipca 1927 roku pisal: W uznaniu dotychczasowej pracy, w przekonaniu, że Czcigodny Ks. Doktor nadal sumiennie i gorliwie pracować będzie, powierzam Mu od 1. października b.r. katedrę historii kościelnej i patrologii, mianując Go zarazem profesorem nadzwyczajnym Arcybiskupiego Seminarium Duchownego. Dodajmy, że dwa lata później otrzymał tytuł profesora zwyczajnego. Trzeba też zauważyć, że był to czas, w którym z inicjatywy kardynała Hlonda nastąpiła reorganizacja seminariów duchownych obu wielkopolskich archidiecezji. Przedłużono studia alumnów do sześciu lat, z tym, że w Gnieźnie miano odbywać dwuletnie studia filozoficzne (z historią i patrologią), w Poznaniu - czteroletnie studia teologiczne. Ksiądz Nowacki trwał na tym stanowisku do roku 1939, a po przerwie okupacyjnej ponownie podjął obowiązki profesorskie zrazu w Gnieźnie, a od 4 listopada 1947 w Poznaniu, gdy ukończono już podstawowy zrąb odbudowy zniszczonego podczas wojny gmachu Seminarium Duchownego. Był wykładowcą historii Kościoła do roku 1961, natomiast wykłady z patrologii i seminarium naukowe prowadził do końca życia.

Wykładowcą był znamienitym. Z ogromną pasją i zaangażowaniem dzielił się ze słuchaczami sumą swojej wiedzy, która w wielu wypadkach była wynikiem jego własnych uprzednich drobiazgowych analiz i przemyśleń. Imponował nam mnóstwem szczegółowych informacji o wydarzeniach, które mogły wydawać się pozornie nieinteresujące. Ożywiał je, tworząc - rzec można plastyczny historyczny pejzaż. W jego wykładzie nie było nic z monotonii, nic $z$ hermetycznej lectio continua. Głos modulował, chwilami wydawało się nam, że zatracał świadomość tego, że my go słuchamy. To, co mówił było przeży- 
ciem jakby dla niego samego. Dodać wszakże trzeba, iż zdawaliśmy sobie sprawę, że mamy do czynienia z wielką historią. Malując dzieje Kościoła nie tuszował jego potknięć, robił to jednak łagodnie, jakby chciał nam oszczędzić mówienia źle o czymś, co bardzo ukochał i co my mieliśmy ukochać. Nie był syntetykiem w wykładach, ale to, co przekazał - wydaje się - stworzyło nam wystarczające podwaliny wiedzy o Kościele, w którym zaczynaliśmy świadomie i aktywnie zaznaczać swoją obecność.

Wykładał też patrologię, ale na terenie tej literatury starochrześcijańskiej aż tak pewnie się nie czuł, nie mógł tu ujawnić talentów swego analitycznego umysłu, a do syntezy - której niezawodnie oczekiwaliśmy - nie był zbytnio skłonny. Odtwarzał głównie treść podręcznika Rauschena, wówczas szeroko zadomowionego $w$ krajach niemieckiego obszaru językowego, który to podręcznik sam na język polski przetłumaczył i opracował.

Gdy w roku 1938 habilitowat się na Wydziale Teologicznym Uniwersytetu Jana Kazimierza we Lwowie, dał się już wcześniej dobrze poznać polskiej nauce historycznej jako autor kilkudziesięciu drukowanych przyczynków i studiów głównie z zakresu dziejów średniowiecznych. Rozprawa habilitacyjna, napisana po łacinie, dotyczyła prerogatyw i godności prymasowskiej arcybiskupów gnieźnieńskich. Miejsce habilitacji nie było od początku przesądzone. Jak wynika z zachowanej, a nieznanej dotąd korespondencji księdza Nowackiego z księdzem profesorem Tadeuszem Glemmą z Krakowa, nasz autor brał także pod uwagę Uniwersytet Jagielloński. Z korespondencji zdaje się wyraźnie wynikać, iż ksiądz Glemma sugerował poznańskiemu historykowi późniejsze związanie się z Wszechnicą Jagiellońską. Ostatecznie wszakże wybór padł na Uniwersytet Jana Kazimierza, gdzie dziesięć lat wcześniej przedstawił rozprawę doktorską i gdzie - dodajmy - znaczącą coraz bardziej i wpływową pozycję miał ksiądz profesor Aleksy Klawek ze środowiska poznańskiego ${ }^{5}$. Niewykluczone, że i ta okoliczność miała tu pewne znaczenie.

Odrębnym, a wielce ważnym polem aktywności księdza Nowackiego była jego praca nad dziedzictwem archiwalnym Kościoła poznańskiego. Mamy tu na myśli nie tyle okoliczność, iż dziedzictwo to $w$ przeważającej mierze stanowiło bazę źródłową dla jego badań naukowych, ile raczej fakt, iż stał się on tego dziedzictwa gospodarzem i serdecznym opiekunem. Zaczęło się to na

\footnotetext{
${ }^{5} \mathrm{Na}$ ten problem zwrócił mi uwagę p. dr hab. Krzysztof R. Prokop, który w krakowskim archiwum "Naszej Przeszłości" zauważył dwanaście listów księdza Józefa Nowackiego do księdza Tadeusza Glemmy z lat 1933-1952. Nie natrafiono dotąd w Poznaniu na listy księdza Glemmy do księdza Nowackiego. Pan Prokop przekazał mi zapewnienie, iż zamierza przygotować przyczynek pod roboczym tytułem: Niedoszła habilitacja księdza Józefa Nowackiego na Wydziale Teologicznym Uniwersytetu Jagiellońskiego w świetle jego listów do księdza profesora Tadeusza Glemmy. Tekst ten miałby się ukazać w kolejnym tomie niniejszego wydawnictwa.
} 
dobre z dniem 15 sierpnia 1933 roku, gdy dekretem Kurii Arcybiskupiej z dnia 5 lipca (podpisanym przez biskupa Walentego Dymka, wikariusza generalnego), został powołany na urząd dyrektora Archiwum, Biblioteki i Muzeum Archidiecezjalnych $w$ Poznaniu. Wymieniono $w$ dekrecie zbiory archiwalne, biblioteczne i muzealne, które przechowywane były w jednym gmachu, mianowicie w siedzibie dawnej Akademii Lubrańskiego (w którym ksiądz Nowacki odtąd zamieszkał). W rzeczywistości jednak utożsamiał się z tymi pierwszymi. Trzeba przypomnieć, iż w Poznaniu w roku 1925 otwarto Archiwum Archidiecezjalne, które było pierwszą tego rodzaju, centralną w ramach diecezji, instytucją kościelną w Polsce, która postawiła sobie za cel gromadzenie, przechowywanie i udostępnianie produkcji aktotwórczej zarówno podstawowych organów zarządu diecezją (kancelarii biskupiej, konsystorskiej i kapitulnej) jak też organów terenowych, a więc przede wszystkich parafialnych. Gdy w roku 1933 obejmował ksiądz Nowacki urząd dyrektora Archiwum, od jego otwarcia minęło już lat osiem.

Jego poprzednikiem był ksiądz Edmund Majkowski, człowiek o rozległych zainteresowaniach naukowych i pisarskich (jednak rozproszonych i - wydaje się - nie pogłębionych), numizmatyk, bibliofil, kolekcjoner, także podróżnik. Należał wprawdzie do inicjatorów powstania Archiwum, ale jego zasługi nie wyszły poza pierwsze zręby organizacyjne, niejednokrotnie wręcz dyskusyjne. Zapalony kolekcjoner, łączył niektóre zasoby ze swoim nazwiskiem. Usiłował np. stworzyć - nie bacząc na obowiązującą w archiwistyce zasadę proweniencji, czyli zespołowej przynależności akt - „Archiwum zebrane przez księdza Edmunda Majkowskiego"7. Było to bez wątpienia swoiste curiosum na terenie praktyki archiwalnej. Jego następca musiał więc rozpocząć wiele prac od nowa.

Obejmując urząd dyrektora Archiwum ksiądz Nowacki postawił sobie dwa głównie zadania: uporządkowanie całości (chociażby zrazu prowizoryczne) oraz stworzenie inwentarza archiwalnego. Poza szczupłymi seriami dawnych ksiąg konsystorskich, biskupich i niektórych kapitulnych, ułożonych według inwentarza z XVIII stulecia, reszta zasobu znajdowała się w nieładzie. Jedynie akta personalne i szkolne były w miarę uporządkowane chronologicznie. Ponieważ w roku 1930 przekazano do Archiwum obszerne akta registratury konsystorza z końca XVIII i XIX stulecia, ksiądz Nowacki musiał zająć się najpierw tą spuścizną, chociaż własna pasja naukowa prowadziła go do epoki wcześniejszej. Prowadził jednak równocześnie prace porządkowe nad najstarszymi

\footnotetext{
${ }^{6}$ Zob. F. L e n o r t, Z dziejów organizacji i zasobu Archiwum Archidiecezjalnego w Poznaniu, "Archiwa, Biblioteki i Muzea Kościelne", 15 (1967), s. 5-90 i osobne odbicie.

7 Zob. F. L e n o r t, Z dziejów organizacji i zasobu Archiwum Archidiecezjalnego w Poznaniu, s. 82-84; E. M a j k o w s k i, Życiorys własny i spis prac. Podat do druku J. Ujda. „Nasza Przeszłość" 25 (1966), s. 285-290.
} 
acta episcopalia i acta consistorialia z XV wieku. Zdołał zinwentaryzować akta kościołów parafialnych. Z wielkim znawstwem pracował nad zbiorem dokumentów pergaminowych (od roku 1235). Pominął w tym wypadku ich przynależność kancelaryjną i stworzył zbiór liczący 451 dokumentów. Mniejsze sukcesy odnotowało kierowane przez księdza Nowackiego Archiwum w zakresie statutowego postulatu koncentracji akt, który był założeniem podstawowym w rozumieniu twórców tej instytucji, ale na ten aspekt pracy nie miał ksiądz Nowacki wyłącznego wpływu. Zaopatrzył w indeksy alfabetyczne poszczególne księgi wizytacyjne z XVII i XVIII stulecia. Większość zasobu archiwalnego otrzymała praktyczny inwentarz kartkowy, który w dużej mierze przyczynił się do usprawnienia obsługi korzystających z Archiwum badaczy, których liczba nieustannie rosła (w roku 1935 przekroczyła 900) ${ }^{8}$. Tego rodzaju działalność już u schyłku okresu międzywojennego postawiła Archiwum Archidiecezjalne w Poznaniu w rzędzie przodujących tego typu placówek w Polsce, a księdzu Nowackiemu zjednała $w$ kręgach naukowych szacunek i uznanie. Taką opinię wyrazili np. dwaj podówczas wybitni znawcy teorii i praktyki archiwalnej: Wincenty topaciński i Kazimierz Konarski ${ }^{9}$.

W roku 1939 praca organizacyjna i badawcza księdza Józefa Nowackiego w Archiwum Archidiecezjalnym w Poznaniu była w apogeum swego rozwoju. Mijał szósty rok, gdy ją z zapałem i z rozległymi planami rozpoczynał. Niestety, została tragicznie przerwana. W czasie początkowych działań wojennych zarówno gmach jak i zbiory w niczym nie ucierpiały. Ostatecznie jednak 4 października 1939 roku cały magazyn został przez władze niemieckie opieczętowany i rozpoczął się proces likwidacji Archiwum. Jego zbiory przewożono do pomieszczeń archiwum państwowego, któremu przydano nazwę Reichsarchiv. W skład personelu tej instytucji, razem z innymi archiwistami z terenu Poznania, wszedł również ksiądz Józef Nowacki, który dzięki temu miał okazję śledzić losy tych archiwaliów, co okazało się bezcenne po zakończeniu wojny, gdy rozpoczął się żmudny proces rewindykacji. Warto wspomnieć, że niektóre najcenniejsze zabytki, jeszcze w końcu sierpnia 1939 roku - za radą księdza Nowackiego - ukryto w klasztorze kapucyńskim w Lubartowie, ale Niemcy wywieźli je stamtąd, początkowo do Reichssicherheitshauptamt w Berlinie, skąd następnie zostały przewiezione do Poznania, także do miejscowego Reichsarchiv. Prawdziwa wędrówka naszych zbiorów - śledzona dokładnie przez księdza Nowackiego - miała miejsce począwszy od roku 1942 (obawiano się bombardowania miasta przez Anglosasów). I tak - wspomnijmy - np.

${ }^{8}$ Zob. F. L e n o r t, Z dziejów organizacji i zasobu Archiwum Archidiecezjalnego W Poznaniu, s. 77.

${ }^{9}$ Tamże, s. 79. 
dyplomy pergaminowe i najstarsze księgi sprzed roku 1500, które umieszczono $w$ fortach cytadeli poznańskiej, potem $w$ fortyfikacjach nadodrzańskich koło Sulęcina, niektóre przewożono w głąb Niemiec, znaczną część rozmieszczono w kościołach na prownicji. Te, które zostały w Reichsarchiv, przepadły zupełnie, bo gmach podpaliły prawdopodobnie ustępujące wojska niemieckie. Tak więc dla naszych zbiorów czasem największych strat okazał się rok 1945, a dla księdza Nowackiego i Archiwum Archidiecezjalnego w Poznaniu był to rok drugiego początku ${ }^{10}$.

Po zakończeniu wojny ksiądz Nowacki wrócił wprawdzie do przerwanych w roku 1939 prac i funkcji dyrektora Archiwum i Muzeum, ale czynności, które zrazu musiał wykonywać, dalekie były od stricte naukowych. Powierzono mu obowiązki zorganizowania życia religijnego w parafii archikatedralnej. Niebawem otrzymał nowe zlecenie od władzy duchownej. Od kwietnia 1946 roku z ogromną energią podejmował starania o odzyskanie rozproszonych zabytków archiwalnych, bibliotecznych i muzealnych także archidiecezji gnieźnieńskiej i diecezji włocławskiej. Był członkiem Komisji Doradczej Odbudowy Archikatedry Poznańskiej. Skrzętnie przygotowywał dokumentację historyczną do jej odbudowy, co w efekcie umożliwiło jej regotyzację. I to, co najważniejsze: na nowo tworzył sobie warsztat pracy twórczej, który umożliwił mu powrót do przerwanych badań naukowych.

Plonem tych badań było przeszło osiemdziesiąt prac drukowanych. Byłoby ich zapewne jeszcze więcej, gdyby nie ta tragiczna okupacyjna przerwa, a potem mało przyjazna sytuacja wydawnicza. Nie licząc drobnego doniesienia w "Przeglądzie Teologicznym” z roku 1928 na temat książki J. Metzlera o św. Piotrze Kanizjuszu, za znaczący początek jego edytorskiej aktywności należy uznać rok 1929, w którym ukazał się jego przekład niemieckiego podręcznika Gerharda Rauschena pt.: „Zarys patrologii. Pisma Ojców Kościoła i nauka w nich zawarta", tłumaczony z ósmego i dziewiątego wydania przez wrocławskiego profesora Josepha Wittiga ${ }^{11}$. Podręcznik ten długo należał do podstawowych narzędzi edukacji patrystycznej w polskich seminariach duchownych.

${ }^{10}$ Zob. J. N o w a c k i, Losy wojenne Archiwum Archidiecezjalnego w Poznaniu, "Sprawozdania Towarzystwa Przyjaciół Nauk Poznańskiego", 13 (1945/1946) s. 44-46; F. L e n o r t, Z dziejów organizacji i zasobu Archiwum Archidiecezjalnego w Poznaniu, 80-82; K. Ś m i g i e I, Losy archiwów, bibliotek i muzeów kościelnych pod rządami A. Greisera (1939-1945), „Archiwa, Biblioteki i Muzea Kościelne”, 32 (1976) s. 275-278.

11 Zob. Szczepan P i e s z c z o c h, Ksiądz Józef Nowacki jako patrolog, w: Ecclesia Posnaniensis. Opuscula Mariano Banaszak septuagenario dedicata. Poznań 1998 s. 267-272. Autor dotyka tu sprawy osobistego dramatu Josepha Wittiga z Kosciołem, zakończonego ostatecznie pozytywnie. 
Nie licząc kilkudziesięciu przyczynków naukowych opublikowanych przed rokiem 1939, w tym między innymi o arcybiskupie gnieźnieńskim Januszu i nieznanym synodzie prowincjonalnym z roku $1258^{12}$, na szczególną uwagę zasługują dwie ważne monografie. Pierwsza to obszerna publikacja książkowa, wydana w roku 1934 w serii "Studia Gnesnensia” pt.: Opactwo św. Gotarda w Szpetalu pod Włocławkiem zakonu cysterskiego (ok. 1228-1285-1358). Przyczynek do misji pruskiej biskupa Chrystiana ${ }^{13}$. Podkreślano, że mimo szczupłych dochowanych źródeł historycznych, autor w mistrzowski sposób je wykorzystał i zrekonstruował krótkotrwałe dzieje klasztoru cysterskiego w Szpetalu, w tym i wcześniejsze początki tamtejszego kościoła św. Gotarda. Przede wszystkim jednak włączył się w nurt badań nad dziejami misji pruskiej, podjętej przez cystersów na początku XII wieku. Łączenie tej misji z fundacją szpetalską budziło jednak wśród historyków pewne wątpliwości. Autor dał jednak przykład znakomitej analizy i wyobraźni historycznej (może nieco nadmiernej).

Druga publikacja, którą z tego pierwszego okresu twórczości księdza Nowackiego należałoby tu szczególnie podkreślić, to opracowane w języku łacińskim obszerne studium pt.: „De archiepiscopi Gnesnensis dignitate ac praerogativa primatiali", opublikowane we Lwowie w "Collectanea Theologica" w roku 1937 (także w odrębnym odbiciu). Ta sumienna rozprawa o prymasowskiej godności i wypływających z niej uprawnieniach arcybiskupów gnieźnieńskich byla podyktowana także potrzebą chwili, w związku z polemiką prowadzoną po uzyskaniu przez Polskę niepodległości, głównie w środowisku warszawskim, wokół pytania: czy tytuł prymasowski należy się metropolicie gnieźnieńskiemu czy warszawskiemu? Ponowne zwrócenie uwagi na złożoną genezę prymasostwa polskiego oraz na zyskiwanie przez prymasów dalszych uprawnień jurysdykcyjnych, także $w$ zakresie państwowym, okazało się ważnym wkładem autora dla uporządkowania całej sprawy. Publikacja ta - aczkolwiek wysoko oceniona przez krytykę naukową ${ }^{14}-$ wywołała dalszą polemikę.

12 Zob. np. recenzję T. S i I n i c k i e g o w „Rocznikach Historycznych”, 11 (1935) s. $90-91$.

${ }^{13}$ K. G ó r s k i, „Kwartalnik Historyczny”, 48 (1934) s. 637-640; P. D a v i d, "Revue d'Histoire Ecclesiastique", 30 (1934) s. 787; M. N i w i ń s k i, "Przegląd Powszechny", 204 (1934) s. 400-401; M. N i w i ń s k i, "Zapiski Towarzystwa Naukowego w Toruniu", 10 (1935/1937) s. 70-73; K. K a n t a k, "Collectana Theologica”, 16 (1935) s. 127-129; K. T y m i e n i e c k i, "Roczniki Historyczne", 11 (1935) s. 88-90. Zob. też: St. Gotthard von Szpetal, eine vergessene Cistercienserabtei in Polen, "Cistercienser-Chronik", 48 (1936) s. 44-50.

14 Zob. np. H. R y b u s, "Roczniki Historyczne”, 14 (1938) s. 152-160. Autor poddat także zdecydowanej krytyce, uznaną za bałamutną, publikację księdza Władysława Kwiatkowskiego pt.: Kwestia prymasostwa polskiego pod koniec XVIII wieku. Także: J. N ow a c ki, Jeszcze o prymasostwie, „Tęcza”, 1938 nr 13 s. 77-80. 
W okresie powojennym ksiądz Nowacki wcześnie ujawnił swój talent w zakresie edytorstwa źródeł historycznych i w ten sposób utrwalił swoją pozycję w kręgu mediewistów polskich. W roku 1950 bowiem, staraniem Poznańskiego Towarzystwa Przyjaciół Nauk, wydał "Księgę uposażenia diecezji poznańskiej z roku 1510 (Liber beneficiorum dioecesis Posnaniensis anni 1510)15. Już na zjeździe historyków polskich w Poznaniu w roku 1925 zwrócono uwagę na brak tego rodzaju wydawnictwa $w$ odniesieniu do najstarszej diecezji polskiej, w sytuacji, gdy kilka z nich (lubuska, wrocławska, krakowska, gnieźnieńska, włocławska) dawno już tę lukę zapełniło. Wyrażano uznanie dla wydawcy, który mimo, iż wiele z materiałów przygotowanych przez niego jeszcze przed wojna, przepadło podczas okupacji niemieckiej, nie zniechęcony podjął dzieło ponownie i obdarzył w ten sposób naukę polską tym bezcennym źródłem do kościelnych dziejów, głównie gospodarczych.

Ukoronowaniem wszakże działalności naukowej i pisarskiej księdza Józefa Nowackiego było potężne, dwutomowe dzieło pt.: „Dzieje Archidiecezji Poznańskiej", opublikowane w Poznaniu w latach 1959 i 1966. Jest to łącznie ponad 2000 stron, nie licząc wielu aneksów, map i ilustracji. Pierwszy tom to "Kościół katedralny w Poznaniu" ze szczególnie znaczącym i obszernym studium na temat początków biskupstwa w Poznaniu, drugi - to „Archidiecezja Poznańska w granicach historycznych i jej ustrój". Miał być ciąg dalszy, czyli tom trzeci. Autor w przedmowie do tomu pierwszego pisał: Trzeci tom poświęcamy Kapitule Metropolitalnej w Poznaniu. Gotowa już pierwsza jego część rozpatruje jej ustrój, majątek i dzieje. Druga część obejmie w alfabetycznym układzie wykaz jej członków ze zwięzłymi o nich wiadomościami biograficznymi. Niestety, nie natrafiono po jego śmierci (zmarł przy korekcie tomu drugiego) na ślad tego przygotowanego już w części tomu trzeciego. Wielu historyków przez dłuższy czas pytało: co się dzieje z tomem o Kapitule? Niestety, nic nie odnaleziono. Piszący te słowa, również zainteresowany, zauważył po latach w miejscowym Archiwum Archidiecezjalnym jedynie średniej wielkości karton z luźnymi wypisami (raczej tylko dla autora czytelnymi) - ślad żmudnej naukowej kwerendy. To wszakże, co zdążył opublikować, sprawiło, iż zapisał się na trwałe złotymi zgłoskami w kościelnej historiografii Wielkopolski.

Nie trzeba dodawać, z jakim uznaniem przyjęła to opus magnum polska nauka historyczna. Podkreślano, że dzieło to jest wzorem dla podobnych tego

15 Zob. S. I n g I o t, „Roczniki Dziejów Społecznych i Gospodarczych”, 13 (1951) s. 299-3001; H. E. W y c z a w s k i, "Polonia Sacra", 4 (1951) z. 2 s. 172-174; Z. Ka cz ma r c z y k, K. K a c z m a r c z y k, "Czasopismo Prawno-Historyczne", 4 (1952) s. 487-492; E. B. F ry d e, "The English Historical Review", 67 (1952) s. 437-438. Zob. także: M. B a n a s zak, Prymasostwo polskie w dziejach Narodu i Koscioła (do roku 1939), w: Na stolicy prymasowskiej w Gnieźnie i w Poznaniu. Szkice o prymasach Polski w okresie niewoli narodowej i w II Rzeczypospolitej. Praca zbiorowa pod redakcją F. Lenorta, Poznań 1982 s. 35-57; F. L e n o r t, Uwagi o historiografii prymasostwa polskiego, tamże s. 59-81. 
rodzaju opracowań w innych diecezjach. Mówiono, że dzisiaj tylko zespół historyków mógłby podjąć się tak szeroko zakrojonej pracy, którą ksiądz Nowacki wykonał sam jeden (Karol Górski). Podkreślano, że autor nie poprzestał na wykorzystaniu opinii poprzednich badaczy przedmiotu, lecz sam skontrolował ich sądy, wysuwając własny pogląd na wiele spraw, a znaczne partie dzieła musiał stworzyć od podstaw, gdyż wiele zagadnień nie było dotychczas przedmiotem zainteresowania historyków (Julia Tazbirowa) ${ }^{16}$. Fakt, że po dzieto to, zwłaszcza po pierwszy tom sięgnie zarówno historyk jak i historyk sztuki, znajdując tam do swych badań kopalnię wiadomości - było podkreślane niejednokrotnie ${ }^{17}$.

Historiografia kościelna Wielkopolski przez ostatnie czterdziestolecie - po odejściu księdza Józefa Nowackiego - rozwinęła się niepomiernie. Jego ustalenia stały się $w$ wielu wypadkach znakomitym punktem wyjścia do dalszych dociekań. Wiele obszarów naszej przeszłości kościelnej wzbogaciło się o cenne monografie. Nie miejsce tu, aby je szczegółowo wymieniać. W środowisku Wydziału Teologicznego UAM została przygotowana obszerna dokumentacja tej tematyki ${ }^{18}$.

Jest wszakże jeden segment badań naszego autora, pomieszczony w pierwszym tomie jego "Dziejów", który ze zrozumiałych względów wzbudził szczególne zainteresowanie, gdyż dotyczył początku biskupstwa poznańskiego, a więc $w$ gruncie rzeczy początków organizacji kościelnej na ziemiach polskich. Panującą dotąd dość powszechnie tezę Paula Kehra o misyjnym statusie biskupa Jordana i Ungera, ksiądz Nowacki podważył zdecydowanie, wysuwając domniemanie, że Jordan od 968 roku był biskupem diecezjalnym a nie misyjnym oraz, że jego diecezja (poznańska) do roku 1000 obejmowała cały kraj Mieszka i nie podlegała metropolii magdeburskiej, zależała natomiast bezpośrednio od Stolicy Apostolskiej na podstawie przywileju egzempcji. Ten ostatni element dowodzenia został wzmocniony poprzez wyniki badań księdza Anzelma Weissa, który dowiódł, że istniał status prawny bezpośredniej podległości Stolicy Apostolskiej niektórych biskupstw w początkowej fazie ich tworzenia i organizacji ${ }^{19}$. Najnowsza historiografia ukazała w tym obszarze badań zdecy-

${ }^{16} \mathrm{~J}$. T a z b i r o w a, "Przegląd Historyczny", 51 (1960) z. 4 s. 760-763.

17 A. Gą s i orows ki, T. Ja k i mow i c zó w n a, "Biuletyn Historii Sztuki”, 25 (1963) nr 1 s. 83-89. Jest to gruntowna i obszerna analiza monografii Nowackiego o katedrze, ze szczególnym podkreśleniem jej przydatności historyka sztuki. Zob. także: J. G ott s ch a I k, "Archiv für Schlesische Kirchengeschichte", 23 (1965) s. 282-283; J. Kło c zow ski, "Revue d'Histoire Ecclesiastique" 61 (1966) nr 1 s. 168-170.

${ }_{18}$ Zob. F. L e n o r t, M. P r z e p i ó r a, Historiografia Archidiecezji Poznańskiej. Dokumentacja za lata 1945-2005, Poznań 2007 (w druku).

${ }^{19}$ Zob. np. M. B a n a s z a k, O początkach biskupstwa poznańskiego dyskusyjnie, Poznań 2002. Tekst ten wcześniej ukazał się pod tytułem: Charakter prawny biskupów Jordana i Ungera, w "Naszej Przeszłości”, 30 (1969) s. 43-123. Autor dokładnie relacjonuje dyskusję naukową na ten temat. 
dowanie nowe, poszerzone możliwości interpretacyjne ${ }^{20}$. Sam tekst księdza Nowackiego - o którym tu mowa - doczekał się wznowienia w oddzielnej publikacji, co zapewne przyczyniło się do ożywienia świadomości historycznej wokół początków najstarszego biskupstwa polskiego ${ }^{21}$. Wypadnie tu dodać, iż z tomu drugiego "Dziejów" zostały ostatnio wznowione dwa inne fragmenty, które przypomniały nam przeszłość synodów diecezji poznańskiej i zawiłe początki oraz dzieje naszego Seminarium Duchownego ${ }^{22}$.

Od odejścia księdza Józefa Nowackiego minęło z górą lat czterdzieści. Pozostały jego dzieła - owoc mrówczej pracy - rozświetlające mroki naszej kościelnej przeszłości. On sam - wydaje się - coraz bardziej przesuwać się w naszej pamięci w odległą krainę cieni. Maleją szeregi tych, którzy mogą o nim powiedzieć: znaliśmy go osobiście.

Z mowy pożegnalnej arcybiskupa Antoniego Baraniaka, 2 maja 1964 roku:

Archidiecezję Poznańską spotkat dotkliwy cios. Opuścit ją Mąż wielki, zakochany przez całe życie w jej tysiącletnich dziejach i zagłębiony w rozwiązywaniu trudnych problemów naszej przeszłości.

Historia Kościoła, szczególnie historia Kościoła w Polsce stała się dla niego polem dociekań naukowych w tym szczególnie celu, aby stać się nauczycielką życia, abyśmy poznawszy swoją chlubną przeszłość mogli dzisiejszemu światu powiedzieć: my nie od dziś, czy wczoraj. Nasza wiara i nasze przekonania sięgają tysiąca lat i stanowią nieodłączny fundament kultury narodowej.

20 Zob. np. G. L a b u d a, O najstarszej organizacji Kościoła w Polsce, "Przegląd Powszechny", (1984) nr 6 s. 373-396; t e n ż e, Mieszko I, Wrocław 2002; A. W e is s, Biskupstwa bezpośrednio zależne od Stolicy Apostolskiej w Sredniowiecznej Europie, Lublin 1992; D. A. S i k o r s k i, O rzekomej instytucji biskupstwa bezpośrednio zależnego od Stolicy Apostolskiej. Przyczynek do problemu statusu prawnego biskupów polskich przed rokiem 1000, "Czasopismo Prawno-Historyczne", 55 (2003) z. 2 s. 157-185; R. M i c h a ł o w s k i, Zjazd gnieźnieński. Religijne przesłanki powstania arcybiskupstwa gnieźnieńskiego, Wrocław 2005.

21 J. N o w a c k i, Początki biskupstwa poznańskiego, Poznań 2000.

22 J. Now a c k i, Synody diecezji poznańskiej, Poznań 2004; t e n ż e: Dzieje Seminarium Duchownego w Poznaniu, Poznań 2006. Do książki dodano studium L. Piechnika, Seminarium Diecezjalne w Poznaniu w latach 1564-1614. Okres jezuicki oraz opracowanie W. Hozakowskiego pt. Reorganizacja Seminarium Duchownego w Poznaniu za arcybiskupa Marcina Dunina. 